\title{
Effect of split application of different $N$ rates on productivity and nitrogen use efficiency of bread wheat (Triticum aestivum L.)
}

\author{
Fresew Belete ${ }^{1,2^{*}} \mathbb{D}$, Nigussie Dechassa ${ }^{1}$, Adamu Molla $^{3}$ and Tamado Tana ${ }^{1}$
}

\begin{abstract}
Background: Bread wheat is an important staple and cash crop grown by smallholder farmers in the central highlands of Ethiopia. However, the productivity of the crop is constrained by low soil fertility and poor nitrogen fertilizer management in the area. For example, there is limited information on optimum rates and timing of nitrogen fertilizer application in the area. Therefore, a field experiment was conducted for two consecutive years (2014 and 2015) under rain-fed condition to determine the effect of $N$ fertilizer rate and timing of application on grain yield and nitrogen use efficiency of bread wheat. Factorial combinations of three $N$ levels and five application times plus one control were laid out in a randomized complete block design with four replications.

Results: The optimum grain yield $\left(6060.04 \mathrm{~kg} \mathrm{ha}^{-1}\right.$ ) was recorded when $240 \mathrm{~kg} \mathrm{~N} \mathrm{ha}^{-1}$ was applied $1 / 4$ at sowing, $1 / 2$ at tillering and $1 / 4$ at booting, and it showed no significant additional response to $N$ fertilizer above this rate. Higher $N$ level $\left(360 \mathrm{~kg} \mathrm{~N} \mathrm{ha}^{-1}\right)$ always increased $N$ content in the grain and nitrogen uptake by wheat crop. The best recovery of nitrogen (59.74\%) by wheat was found when $120 \mathrm{~kg}$ of nitrogen was applied $(1 / 4$ at sowing, $1 / 2$ at tillering and $1 / 4$ at booting). The nitrogen use efficiency traits decreased with increased $N$ rate $\left(120-360 \mathrm{~kg} \mathrm{~N} \mathrm{ha}^{-1}\right)$ indicating poor $N$ utilization. The split application of nitrogen ( $1 / 4$ at sowing, $1 / 2$ at tillering and $1 / 4$ at booting) produced the highest nitrogen use efficiency traits.
\end{abstract}

Conclusion: The application of $240 \mathrm{~kg} \mathrm{~N} \mathrm{ha}^{-1}$ in three split doses $\left(T_{5}\right)$ was required to obtain optimum wheat yield. In addition, increasing the rate of nitrogen beyond $120 \mathrm{~kg} \mathrm{~N} \mathrm{ha}^{-1}$ decreased nitrogen use efficiency traits.

Keywords: Efficiency, Recovery, Split, Uptake, Yield

\section{Background}

Bread wheat (Triticum aestivum L.) is one of the most important cereal crops in the world in terms of area coverage and production. It is a major source of nutrition for humans and livestock, estimated to contribute as much as 60 million tonnes of protein per year [1]. The total worldwide production of wheat in 2012 was around 671 million tonnes on an area of 215 million ha [2]. In Ethiopia, wheat is grown approximately by 4.8 million farmers on 1.6 million hectares representing $13.33 \%$ of total crop area [3]. Data aggregated at a worldwide level over

\footnotetext{
*Correspondence: beletefresew@gmail.com

1 School of Plant Sciences, College of Agriculture and Environmental

Sciences, Haramaya University, P.O. Box 138, Dire Dawa, Ethiopia

Full list of author information is available at the end of the article
}

several decades have shown a strong link between agriculture production and fertilizer use [4]. Of the nutrients, nitrogen $(\mathrm{N})$ is frequently regarded as the single most important mineral nutrient limiting crop production in many agricultural crops worldwide, and it is needed in large amount, as it constitutes $1-4 \%$ of the plant dry matter [5]. However, the average yield of wheat in Ethiopia is very low; it is about 2.5 ton/ha as compared to the world's average of about $3.4 \mathrm{ton} / \mathrm{ha}$ [2]. The low mean national yield of wheat is mainly the result of depleted soil fertility, especially nitrogen $(N)$ deficiency, which is often encountered in cool wet areas or in soils that are frequently water logged such as the highland Vertisols. Therefore, greater usage of chemical fertilizer has been advocated as 
a primary means of increasing wheat grain yield in Ethiopia [6].

Although $N$ is the key element in increasing productivity and the increase of agricultural food production worldwide over the past four decades, a small fraction of this fertilizer is taken up by the plant [7], being $33 \%$ for wheat [8]. Poor $N$ recovery is a function of $N$ flows to competing pathways such as gaseous $N$ losses, leaching and biological immobilization and in-efficiencies in crop $N$ uptake and utilization $[9,10]$. However, adoption of appropriate $N$ fertilizer management practices is reported to increase $N$ recovery up to $70-80 \%$ [11]. Split application of $N$ is one of the methods to improve $N$ use by the crop while reducing the nutrient loss through leaching, denitrification, runoff and volatilization [12]. Some research findings indicated that late season $N$ application as dry fertilizer material was effective in attaining higher $N$ recovery and use efficiency [13]. In addition, determining the right $N$ fertilizer rates and timing of application is decisive factor in obtaining higher yields [14].

In many parts of the world, limited research has been done on the effect of split application of $N$ for wheat and its association with grain yield and NUE [15], which is also true in Ethiopia where information on the subject is meager. Besides, matching crop $N$ demand with available soil $N$ has been challenging for wheat producers in Enewari due to the susceptibility of Vertisols to water logging, which leads to denitrification, leaching and runoff losses during heavy rainfall [12]. According to Molla [16], this forced farmers of Enewari to apply as large as $256 \mathrm{~kg} \mathrm{~N} \mathrm{ha}^{-1}$ (some even apply more) which is by far higher than the blanket recommendation $\left(87 \mathrm{~kg} \mathrm{~N} \mathrm{ha}^{-1}\right)$. However, the optimum rate of nitrogen fertilizer for wheat production in the study area and its time of application are not yet investigated. This study was, therefore, conducted to determine the effect of $N$ levels and time of application on yield and nitrogen use efficiency of bread wheat.

\section{Methods}

\section{The study site}

The study was conducted for two consecutive years during 2014 and 2015 main cropping seasons in the district of Moretina Jiru at the Enewari experimental field station in the central highlands of Ethiopia. Enewari is located at $9^{\circ} 52^{\prime} \mathrm{N}$ latitude, $39^{\circ} 10^{\prime} \mathrm{E}$ longitude at an altitude of 2680 meters above sea level. This area is typical of the rain-fed wheat-growing regions of Ethiopia with average annual rainfall of $1153.69 \mathrm{~mm}$. The dominant soil type of the area is Vertisols which are known for their high water logging and drainage problems. Figure 1 shows monthly total rainfall and monthly mean temperatures at the experimental site over the 2-year study period.

Prior to planting, the surface $(0-20 \mathrm{~cm})$ soil samples from ten spots across the experimental field were collected, composited and analyzed for determining selected soil physicochemical properties at Debre Berhan Agricultural Research Center following the procedure outlined by [17]. Values for the selected physicochemical properties are presented in Table 1.

\section{Description of the study materials}

Fertilizer sources were urea $(46 \% N)$ for nitrogen fertilizer and triple superphosphate $\left(\begin{array}{lll}46 \% & \mathrm{P}_{2} \mathrm{O}_{5}\end{array}\right)$ for phosphorus fertilizer. A wheat variety called Menze (HAR-3008) was used as a test crop which was developed and released by DBARC (Debre Berhan Agriculture Research Center) in 2007. It has been widely promoted

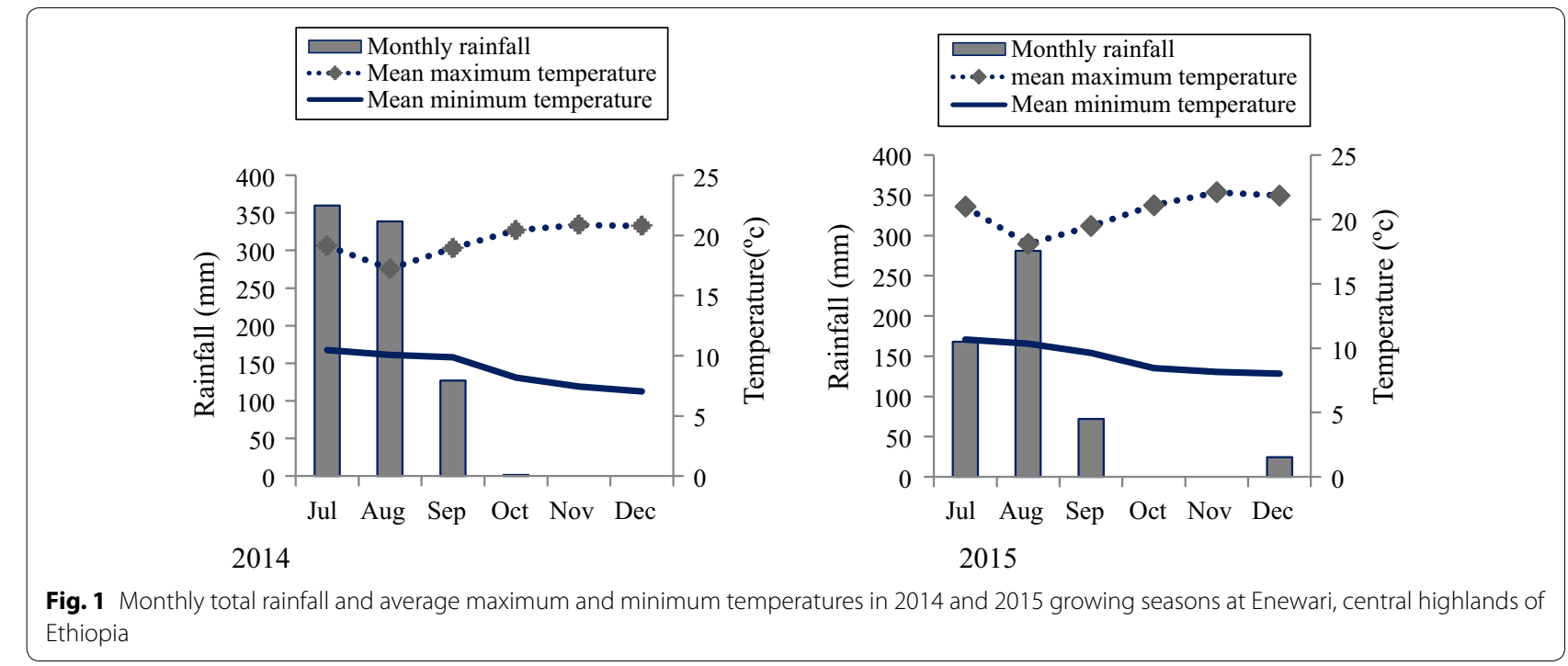


Table 1 Soil physicochemical properties at the depth of 0-20 cm during the years of 2014 and 2015 before sowing of bread wheat

\begin{tabular}{|c|c|c|c|c|}
\hline \multirow[t]{2}{*}{ Parameter } & \multicolumn{2}{|l|}{ Value } & \multirow[t]{2}{*}{ Rating } & \multirow[t]{2}{*}{ References } \\
\hline & Year 2014 & Year 2015 & & \\
\hline Sand & 15 & 12 & - & - \\
\hline Silt & 18 & 17 & - & - \\
\hline Clay & 67 & 71 & - & - \\
\hline Texture class & Clay & Clay & - & - \\
\hline $\mathrm{pH}$ & 7.02 & 7 & Neutral & Tekalign Tadesse [42] \\
\hline Organic carbon (\%) & 1.08 & 1.15 & Low & Tekalign Tadesse [42] \\
\hline Total N (\%) & 0.08 & 0.06 & Low & Tekalign Tadesse [42] \\
\hline Av. P (ppm) & 6.54 & 7.82 & Low & Olsen et al. [43] \\
\hline CEC $[\mathrm{cmol}(+) / \mathrm{kg}$ soil $]$ & 48.75 & 45.25 & Very high & Metson [44] \\
\hline Exchangeable K & 0.23 & 0.2 & Low & Metson [44] \\
\hline
\end{tabular}

for its resistance to yellow rust and with a yield potential of $1900-3300 \mathrm{~kg} \mathrm{ha}^{-1}$ high yielder in Moretina Jiru district, Enewari area. The variety is medium in maturity (154 days), with a medium stature of $64 \mathrm{~cm} \mathrm{[18].}$

\section{Treatments and experimental design}

The treatments consisted of complete factorial combinations of three $N$ fertilizer rates and five split $N$ applications, plus one unfertilized control. The three $N$-fertilization levels were 120, 240 and $360 \mathrm{~kg} \mathrm{~N} \mathrm{ha}^{-1}$. The five $N$ split application timings were adjusted according to Zadoks decimal growth stage for wheat [19] at the time when the moisture is available for nutrient dissolution and absorption. These application timings were: $T_{1}=N$ applied $1 / 2$ at sowing and $1 / 2$ at tillering (Zadok scale 21-22); $T_{2}=$ all $N$ applied at tillering (Zadok scale 21-22); $T_{3}=N$ applied $1 / 2$ at tillering (Zadok scale 21-22) and $1 / 2$ at booting (Zadok scale $41-45) ; T_{4}=N$ applied $1 / 3$ at sowing, $1 / 3$ at tillering (Zadok scale $21-22$ ) and $1 / 3$ at booting (Zadok scale 41-45); and $T_{5}=N$ applied $1 / 4$ at sowing, $1 / 2$ at tillering (Zadok scale $21-22$ ) and $1 / 4$ at booting (Zadok scale 41-45).

These treatments were laid out in a Randomized Complete Block Design (RCBD) with four replications. The gross plot size of each treatment was $2 \mathrm{~m} \times 3 \mathrm{~m}\left(6 \mathrm{~m}^{2}\right)$ accommodating eight rows spaced $20 \mathrm{~cm}$ apart. The plot size for planting was $1.6 \mathrm{~m} \times 3.0 \mathrm{~m}\left(4.8 \mathrm{~m}^{2}\right)$, and four central rows were used for data collection and measurement. The distance between the plots and replications was kept at $0.5 \mathrm{~m}$ and $1 \mathrm{~m}$ apart, respectively.

\section{Crop management}

Wheat seed was sown by drilling in rows at the recommended rate of $150 \mathrm{~kg} \mathrm{ha}^{-1}$ on July 24 in both years.
Each year, all the wheat plots were supplied with triple superphosphate (TSP) at a recommended rate of $138 \mathrm{~kg} \mathrm{P}_{2} \mathrm{O}_{5} \mathrm{ha}^{-1}$ [20]. Similarly, the $N$ was applied in the form of urea (as per the treatment) at planting and the later stage splits were applied by side dressing at the specified Zadoks growth stages. Plots were kept free of weeds by hand weeding. No insecticide or fungicide was applied since there was no outbreak of any insect or disease incidence. Harvesting was done manually using hand sickle in late December.

\section{Data collection and measurements}

In both years, gain yield $\left(\mathrm{kg} \mathrm{ha}^{-1}\right)$ was determined from the harvested net plot area of $2.4 \mathrm{~m}^{2}$ and was adjusted to $12.5 \%$ moisture content. At crop maturity, a subsample from each net plot was harvested at ground level, oven-dried at $70{ }^{\circ} \mathrm{C}$ until constant weight was reached for dry weight determination and partitioned into straw and grain. The dried samples were milled and the grain and straw $N$ content of the plant samples was determined using the micro-Kjeldahl method as stated by American Association of Cereal Chemists (AACC) [21]. Total grain $N$ uptake (GNUP) in $\mathrm{kg} \mathrm{ha}^{-1}$ was calculated by multiplying grain yields by $N$ content percentage. Total nitrogen uptake (TNUP) was calculated as the sum of the respective GNUP and SNUP values.

\section{Nitrogen use efficiency traits}

The following $\mathrm{N}$-efficiency parameters were calculated for each treatment following Fageria [22]:

1. Agronomic efficiency $\left(\mathrm{AE}, \mathrm{kg} \mathrm{kg}^{-1}\right)=\frac{G_{\mathrm{f}}-G_{\mathrm{u}}}{N_{\mathrm{a}}}$, where $G_{\mathrm{f}}$ is the grain yield of the fertilized plot $(\mathrm{kg}), G_{\mathrm{u}}$ is the grain yield in the unfertilized plot $(\mathrm{kg})$ and $N_{\mathrm{a}}$ is the quantity of $N$ applied.

2. Agro-physiological efficiency (APE, $\left.\mathrm{kg} \mathrm{kg}^{-1}\right)=\frac{G_{\mathrm{f}}-G_{\mathrm{u}}}{N_{\mathrm{f}}-N_{\mathrm{u}}}$, where $G_{\mathrm{f}}$ is the grain yield of the fertilized plot $(\mathrm{kg})$, $G_{\mathrm{u}}$ is the grain yield in the unfertilized plot $(\mathrm{kg}), N_{\mathrm{f}}$ is the $N$ accumulation in the fertilized plot $(\mathrm{kg})$ and $N_{\mathrm{u}}$ is the $N$ accumulation in the unfertilized plot $(\mathrm{kg})$.

3. Apparent recovery efficiency (ARE, \%) $=\frac{N_{\mathrm{f}}-N_{\mathrm{u}}}{N_{\mathrm{a}}} * 100$, where $N_{\mathrm{f}}$ is the $N$ accumulation by straw and grain in the fertilized plot (kg), $N_{\mathrm{u}}$ is the $N$ accumulation by the straw and grains in the unfertilized plot $(\mathrm{kg})$ and $N_{\mathrm{a}}$ is the quantity of $N$ applied $(\mathrm{kg})$.

4. The nitrogen harvest index (NHI) was determined as the ratio of nitrogen uptake by grain and nitrogen uptake by grain plus straw as described by [22] 


\section{Data analysis}

After verifying the homogeneity of error variances, combined analysis of variance was done using the procedure of SAS [23], and to facilitate factorial analysis, the control was excluded. Mean comparisons were done by Duncan's multiple range tests Gomez and Gomez [24] at the 5\% level.

\section{Results}

\section{Grain yield}

Grain yield was significantly affected by the main effects of year, $N$ rate, time of application as well as the interaction effect of $N$ rate $\times$ time of application. What is more, the interaction effect of year $\times N$ rate, year $\times$ time of application and year $\times N$ rate $\times$ time of application did not affect this parameter (Table 2). The split application of the different $N$ fertilizer rates significantly $(P<0.01)$ affected grain yield. The highest grain yield was obtained in response to the application of $360 \mathrm{~kg} \mathrm{~N}$ ha $^{-1}$ in three splits of $1 / 4$ at sowing, $1 / 2$ at tillering and $1 / 4$ at booting, which was in statistical parity with the grain yield obtained in response to the application of $240 \mathrm{~kg} \mathrm{~N} \mathrm{ha}^{-1}$ $1 / 4$ at sowing, $1 / 2$ at tillering and $1 / 4$ at booting (Table 3 ).

\section{Nitrogen uptake \\ Grain N uptake}

Grain $N$ uptake (GNUP) was significantly influenced by the rate and timing of $N$ application. The interaction effect of $N$ rate $\times$ time of application and year $\times$ time of application also revealed a significant effect on nitrogen

Table 2 Mean squares of analysis of variance for year, $\boldsymbol{N}$ fertilizer rate and time of $\boldsymbol{N}$ application, and their interaction

\begin{tabular}{|c|c|c|c|c|c|c|c|c|}
\hline Source & DF & GY & GNUP & TNUP & $\mathrm{AE}$ & RE & APE & $\mathrm{NHI}$ \\
\hline Y & 1 & $3,386,971^{* *}$ & $789.77^{* *}$ & $6813.22^{* *}$ & $506.38^{* *}$ & $4492.67^{* *}$ & $270.07 n s$ & $839.08^{* *}$ \\
\hline $\operatorname{Rep}(Y)$ & 6 & 61,018 & 30.39 & 120.53 & 18.85 & 35.95 & 51.62 & 18.28 \\
\hline$N$ & 2 & $12,053,826^{* *}$ & $22,875.82^{* *}$ & $43,818^{* *}$ & $2090.92^{* *}$ & $2817.12^{* *}$ & $3064.21^{* *}$ & $120.10^{* *}$ \\
\hline$T$ & 4 & $7,906,065^{* *}$ & $4969.21^{* *}$ & $10,914^{* *}$ & $127.93^{* *}$ & $1622.94^{* *}$ & $287.29^{* *}$ & $108.04^{* *}$ \\
\hline$N \times T$ & 8 & $1,127,802^{* *}$ & $720.28^{* *}$ & $1632.7^{* *}$ & $6.12 \mathrm{~ns}$ & $68.09^{*}$ & $11.19 n s$ & $26.01^{*}$ \\
\hline$Y \times N$ & 2 & 233836ns & $211.25 \mathrm{~ns}$ & $552.37^{*}$ & $43.59^{* *}$ & $142.47^{*}$ & $0.26 \mathrm{~ns}$ & $31.07^{*}$ \\
\hline$Y \times T$ & 4 & $311205 n s$ & $254.56^{*}$ & 59.89ns & $4.32 \mathrm{~ns}$ & $24.27 \mathrm{~ns}$ & $167.89^{* *}$ & $43.21^{* *}$ \\
\hline$Y \times N \times T$ & 8 & $231,387 n s$ & $70.27 \mathrm{~ns}$ & $115.94 \mathrm{~ns}$ & $4.89 \mathrm{~ns}$ & $32.98 \mathrm{~ns}$ & $6.73 \mathrm{~ns}$ & $11.28 \mathrm{~ns}$ \\
\hline Error & 84 & 130,052 & 94.9 & 124.13 & 3.07 & 27.57 & 11.52 & 9.13 \\
\hline
\end{tabular}

$Y$ year, Rep replication, $N N$ rate, $T$ timing of $N$ application, $D f$ degree of freedom, GY grain yield, GNUP grain nitrogen uptake, $T N U P$ total nitrogen uptake, $A E$ agronomic efficiency, $R E$ recovery efficiency, $A P E$ agro-physiological efficiency, $N H I$ nitrogen harvest index

*Significant at the 0.05 probability level; **Significant at $P<0.01$ probability level

Table 3 Grain yield (GY), grain nitrogen uptake (GNUP) and total nitrogen uptake (TNUP) as influenced by the interaction effect of $\boldsymbol{N}$ fertilizer rate and time of $\boldsymbol{N}$ application

\begin{tabular}{|c|c|c|c|c|c|c|c|c|c|}
\hline \multirow[t]{3}{*}{$N$ timing } & \multicolumn{3}{|c|}{$N$ rate $\left(\mathrm{kg} \mathrm{ha}^{-1}\right)$} & \multicolumn{3}{|c|}{$N$ rate $\left(\mathrm{kg} \mathrm{ha}^{-1}\right)$} & \multicolumn{3}{|c|}{$N$ rate $\left(\mathrm{kg} \mathrm{ha}^{-1}\right)$} \\
\hline & 120 & 240 & 360 & 120 & 240 & 360 & 120 & 240 & 360 \\
\hline & \multicolumn{3}{|c|}{$\mathrm{GY}\left(\mathrm{kg} \mathrm{ha}^{-1}\right)$} & \multicolumn{3}{|c|}{ GNUP (kg ha $\left.{ }^{-1}\right)$} & \multicolumn{3}{|c|}{ TNUP $\left(\mathrm{kg} \mathrm{ha}^{-1}\right)$} \\
\hline$T_{1}$ & 4436.40efg & 4948.16def & $5468.85 c d$ & $78.04 f g$ & 106.19de & $127.5 \mathrm{bc}$ & $96.27 \mathrm{fg}$ & 131.45 de & $161.02 \mathrm{bc}$ \\
\hline$T_{2}$ & $4076.89 \mathrm{~g}$ & $4356.21 \mathrm{fg}$ & 4406.88efg & $71.09 \mathrm{~g}$ & $91.56 \mathrm{ef}$ & 100.24de & $85.18 \mathrm{~g}$ & 114.12ef & $124.20 \mathrm{e}$ \\
\hline$T_{3}$ & 4307.19fg & 5050.70de & 4688.13efg & $68.08 \mathrm{~g}$ & $91.22 \mathrm{ef}$ & $94.79 d e f$ & $83.94 \mathrm{~g}$ & $116.11 \mathrm{ef}$ & $121.24 \mathrm{e}$ \\
\hline$T_{4}$ & $4362.17 \mathrm{fg}$ & $5538.53 \mathrm{bcd}$ & 6189.36ab & $70.96 \mathrm{~g}$ & $110.15 \mathrm{~cd}$ & $134.17 a b$ & $92.97 \mathrm{~g}$ & $144.62 \mathrm{~cd}$ & $175.63 b$ \\
\hline$T_{5}$ & 4756.73ef & $6060.04 a b c$ & $6436.00 a$ & $82.49 f g$ & $128.96 b$ & $148.55 a$ & $100.05 \mathrm{fg}$ & $170.04 b$ & $201.47 a$ \\
\hline Treated mean & $5005.48 a$ & & & 100.27 & & & $127.76 a$ & & \\
\hline \multirow[t]{2}{*}{ Control mean } & $1307.96 b$ & & & 24.89 & & & $28.36 b$ & & \\
\hline & & $N R \times N T$ & $\begin{array}{l}\text { Treated versus } \\
\text { control }\end{array}$ & & $N R \times N T$ & $\begin{array}{l}\text { Treated versus } \\
\text { control }\end{array}$ & & $\mathrm{NR} \times \mathrm{NT}$ & $\begin{array}{l}\text { Treated versus } \\
\text { control }\end{array}$ \\
\hline CV (\%) & & 7.2 & 3.84 & & 9.72 & 2.32 & & 8.72 & 1.51 \\
\hline
\end{tabular}

Means followed by the same letters for the same parameter are not significantly different at $P \leq 0.05$

CV Coefficient of variation, NR nitrogen rate, NT time of nitrogen application

$T_{1}=N$ application of $1 / 2$ at sowing and $1 / 2$ at tillering; $T_{2}=N$ application at tillering; $T_{3}=N$ application of $1 / 2$ at tillering and $1 / 2$ booting; $T_{4}=N$ application $1 / 3$ at sowing $1 / 3$ at tillering and $1 / 3$ at booting; and $T_{5}=N$ application $1 / 4$ at sowing, $1 / 2$ at tillering and $1 / 4$ at booting 
uptake by the grain. However, the effect of year, year $\times N$ rate and year $\times N$ rate $\times$ time of application on grain nitrogen uptake was nonsignificant (Table 2). Nitrogen uptake by the grain tended to increase in response to the level of $N$ as it rises from 120 to $360 \mathrm{~kg} \mathrm{ha}^{-1}$ in both growing years. The maximum grain $N$ uptake value $\left(148.55 \mathrm{~kg} \mathrm{ha}^{-1}\right)$ was obtained when $360 \mathrm{~kg} \mathrm{~N} \mathrm{ha}^{-1}$ was applied in three splits ( $1 / 4$ at sowing, $1 / 2$ at tillering and $1 / 4$ at booting) while the lowest value $\left(68.0 \mathrm{~kg} \mathrm{ha}^{-1}\right)$ was recorded when $120 \mathrm{~kg} \mathrm{~N} \mathrm{ha}^{-1}$ was applied equally at tillering and booting $\left(T_{3}\right)$ (Table 3 ). With regard to the interaction effect of year $\times$ time of $N$ application, split application of $N$ three times at sowing, tillering and booting $\left(T_{5}\right)$ produced the highest $N$ uptake value in both growing years while the lowest grain $N$ uptake (78.61 $\mathrm{kg} \mathrm{ha}^{-1}$ ) was recorded when $N$ was applied equally at tillering and booting $\left(T_{3}\right)$ in the year 2014 (Table 4).

\section{Total N uptake}

The analysis of variance indicated that year, $N$ rate, time of $N$ application had highly significant effect on total

Table 4 Interaction effect of the year $\times N$ rate and year $\times N$ timing on GNUP and TNUP of bread wheat

\begin{tabular}{|c|c|c|}
\hline \multirow[t]{3}{*}{$\mathrm{N}$ timing } & \multicolumn{2}{|l|}{ Year } \\
\hline & 2014 & 2015 \\
\hline & \multicolumn{2}{|c|}{ GNUP $\left(\mathrm{kg} \mathrm{ha}^{-1}\right)$} \\
\hline$T_{1}$ & $101.66 c-e$ & $106.15 b-d$ \\
\hline$T_{2}$ & $82.1 \mathrm{fg}$ & 93.15def \\
\hline$T_{3}$ & $78.61 \mathrm{~g}$ & 90.78 efg \\
\hline$T_{4}$ & $106.66 \mathrm{bc}$ & 103.52c-e \\
\hline$T_{5}$ & $119.45 a b$ & $120.55 a$ \\
\hline Treated mean & $100.27 a$ & \\
\hline Control mean & $24.89 b$ & \\
\hline CV (\%) & 9.72 & \\
\hline \multirow[t]{3}{*}{$\mathrm{N}$ rate $\left(\mathrm{kg} \mathrm{ha}^{-1}\right)$} & \multicolumn{2}{|l|}{ Year } \\
\hline & 2014 & 2015 \\
\hline & \multicolumn{2}{|c|}{$\operatorname{TNUP}\left(\mathrm{kg} \mathrm{ha}^{-1}\right)$} \\
\hline 120 & $88.29 d$ & $95.07 d$ \\
\hline 240 & $124.33 c$ & $145.46 b$ \\
\hline 360 & $148.07 b$ & $165.36 a$ \\
\hline Treated mean & $127.76 a$ & \\
\hline Control mean & $28.36 b$ & \\
\hline CV (\%) & 8.72 & \\
\hline
\end{tabular}

Means followed by the same letters for the same parameter are not significantly different at $P \leq 0.05$

CV Coefficient of variation, NR nitrogen rate, NT time of nitrogen application

$T_{1}=N$ application of $1 / 2$ at sowing and $1 / 2$ at tillering; $T_{2}=N$ application at tillering; $T_{3}=N$ application of $1 / 2$ at tillering and $1 / 2$ booting; $T_{4}=N$ application $1 / 3$ at sowing, $1 / 3$ at tillering and $1 / 3$ at booting; and $T_{5}=N$ application $1 / 4$ at sowing, $1 / 2$ at tillering and $1 / 4$ at booting nitrogen uptake of wheat. Likewise, the interaction of $N$ rate $\times$ time of $N$ application, year $\times N$ rate also revealed a significant effect on total nitrogen uptake. But, the interaction effect of year $\times N$ rate $\times$ time of application (Table 3) was not significant. The highest total $N$ uptake value $\left(201.47 \mathrm{~kg} \mathrm{ha}^{-1}\right)$ was attained when $360 \mathrm{~kg} \mathrm{~N} \mathrm{ha}^{-1}$ was applied three times at sowing, tillering and booting $\left(T_{5}\right)$ while the lowest $\left(83.94 \mathrm{~kg} \mathrm{ha}^{-1}\right)$ was recorded when $120 \mathrm{~kg} \mathrm{~N} \mathrm{ha}^{-1}$ was applied equally at tillering and booting $\left(T_{3}\right)$ (Table 3). The year $\times N$ rate interaction shows that wheat $N$ uptake had the highest value $\left(165.4 \mathrm{~kg} \mathrm{~N} \mathrm{ha}^{-1}\right)$ in the year 2015 at the highest $N$ rate while the lowest value $\left(88.3 \mathrm{~kg} \mathrm{~N} \mathrm{ha}^{-1}\right)$ was recorded in 2014 at a rate of $120 \mathrm{~kg} \mathrm{~N} \mathrm{ha}^{-1}$ which was statistically similar to that of 2015 under the same $N$ rate (Table 4).

\section{Nitrogen use efficiency traits Agronomic efficiency}

Nitrogen agronomic efficiency (AE) represents the ability of the plant to increase yield in response to $N$ applied [25]. AE varied significantly according to year, $N$ rates and timing of application, as well as by the interaction of year $\times N$ rate. The interaction between year $\times$ time of application, $N$ rate $\times$ time of application and year $\times N$ rate $\times$ time of application did not show a significant effect on this parameter (Table 2). In 2015, the year with the highest grain yield, the value recorded for $\mathrm{AE}$ was significantly higher than 2014 under all $N$ rates. The application of $120 \mathrm{~kg} \mathrm{~N} \mathrm{ha}^{-1}$ produced the highest $\mathrm{AE}$ value $\left(28.8 \mathrm{~kg} \mathrm{ha}^{-1}\right)$ in 2015 . The lowest $\left(10.47 \mathrm{~kg} \mathrm{~kg}^{-1}\right)$ value was recorded when $360 \mathrm{~kg} \mathrm{~N}^{-1}$ was applied in 2014 (Table 5).

\section{Nitrogen agro-physiological efficiency}

Nitrogen agro-physiological efficiency (APE) represents the ability of a plant to transform $N$ acquired from fertilizer into economic yield (grain) [26]. APE was also influenced by the main effects of $N$ rate and time of application and by the interaction of year $\times$ time of $N$ application. However, the effect of year, the interaction of $N$ rate $\times$ time of application and year $\times N$ rate $\times$ time of $N$ application had no significant effect on this index (Table 2). As to the interaction of year $\times$ time of $N$ application, the highest APE $\left(49.75 \mathrm{~kg} \mathrm{~kg}^{-1}\right)$ was obtained when $N$ was applied in equal split at sowing and tillering in the year 2014 while the lowest value $\left(35.4 \mathrm{~kg} \mathrm{~kg}^{-1}\right)$ was recorded in response to the application of nitrogen only once at tillering $\left(T_{2}\right)$ in 2015 (Table 6).

\section{Nitrogen apparent recovery efficiency}

Nitrogen apparent recovery efficiency (RE) depends on the congruence between plant $N$ demand and the quantity of $N$ released from applied $N$ [27]. RE varied 
Table 5 Interaction effect of year $\times N$ rate on agronomic efficiency (AE), apparent recovery efficiency (RE) and nitrogen harvest index (NHI) of bread wheat

\begin{tabular}{|c|c|c|c|c|c|c|}
\hline \multirow[t]{3}{*}{$\mathrm{N}$ rate $\left(\mathrm{kg} \mathrm{ha}^{-1}\right)$} & \multicolumn{2}{|l|}{ Year } & \multicolumn{2}{|l|}{ Year } & \multicolumn{2}{|l|}{ Year } \\
\hline & 2014 & 2015 & 2014 & 2015 & 2014 & 2015 \\
\hline & \multicolumn{2}{|c|}{$A E\left(\mathrm{~kg} \mathrm{~kg}^{-1}\right)$} & \multicolumn{2}{|l|}{ RE (\%) } & \multicolumn{2}{|l|}{ NHI (\%) } \\
\hline 120 & $22.58 b$ & $28.75 a$ & $44.69 c$ & $59.85 a$ & $84.13 a$ & $78.07 \mathrm{~cd}$ \\
\hline 240 & $14.1 d$ & $18.25 c$ & $37.36 d$ & $50.92 b$ & $82.13 a b$ & $75.60 d$ \\
\hline 360 & $10.47 e$ & $12.47 d$ & $31.5 e$ & $39.48 d$ & $79.32 \mathrm{bc}$ & $76.05 d$ \\
\hline CV (\%) & \multicolumn{2}{|l|}{9.86} & \multicolumn{2}{|l|}{11.94} & \multicolumn{2}{|l|}{3.82} \\
\hline
\end{tabular}

Means followed by the same letters for the same parameter are not significantly different at $P \leq 0.05$

CV Coefficient of variation

Table 6 Interaction effect of year $\times N$ timing on agrophysiological efficiency (APE) and nitrogen harvest index (NHI) of bread wheat

\begin{tabular}{llllll}
\hline & \multicolumn{3}{l}{ Year } & & \multicolumn{2}{l}{ Year } \\
\cline { 2 - 3 } & $\mathbf{2 0 1 4}$ & $\mathbf{2 0 1 5}$ & & $\mathbf{2 0 1 4}$ & $\mathbf{2 0 1 5}$ \\
\hline N timing & APE $\left(\mathrm{kg} \mathrm{kg}^{-1}\right)$ & & & NHI (\%) & \\
$T_{1}$ & $37.21 \mathrm{~d}$ & $38.43 \mathrm{~cd}$ & & $82.8 \mathrm{a}$ & $78.05 \mathrm{bc}$ \\
$T_{2}$ & $45.23 \mathrm{ab}$ & $35.4 \mathrm{~d}$ & & $83.35 \mathrm{a}$ & $80.06 \mathrm{ab}$ \\
$T_{3}$ & $49.75 \mathrm{a}$ & $42.2 \mathrm{bc}$ & & $81.43 \mathrm{ab}$ & $78.34 \mathrm{bc}$ \\
$T_{4}$ & $39.62 \mathrm{~cd}$ & $39.35 \mathrm{~cd}$ & & $81.43 \mathrm{ab}$ & $71.72 \mathrm{~d}$ \\
$T_{5}$ & $36.61 \mathrm{~d}$ & $38.02 \mathrm{~cd}$ & & $80.31 \mathrm{ab}$ & $74.69 \mathrm{~cd}$ \\
$\mathrm{CV}(\%)$ & 8.45 & & & 3.82 & \\
& & & & &
\end{tabular}

Means followed by the same letters for the same parameters are not significantly different at $P \leq 0.05$

CV Coefficient of variation

$T_{1}=N$ application of $1 / 2$ at sowing and $1 / 2$ at tillering; $T_{2}=N$ application at tillering; $T_{3}=N$ application of $1 / 2$ at tillering and $1 / 2$ booting; $T_{4}=N$ application $1 / 3$ at sowing, $1 / 3$ at tillering and $1 / 3$ at booting; and $T_{5}=N$ application $1 / 4$ at sowing, $1 / 2$ at tillering and $1 / 4$ at booting significantly according to year and treatment ( $N$ application timing and $N$ fertilizer rates) as well as by the interaction of $N$ rate $\times$ time of $N$ application $(P<0.05)$ and year $\times N$ rate $(P<0.05)$. But, the interaction effect of year $\times$ time of $N$ application and year $\times N$ rate $\times$ time of $N$ application did not affect recovery efficiency of nitrogen (Table 2). With regard to the interaction effect of year $\times N$ rate, the highest $\mathrm{RE}(59.85 \%)$ was recorded in the year 2015 with the application of $120 \mathrm{~kg} \mathrm{~N} \mathrm{ha}^{-1}$. The lowest RE (31.5\%) was recorded with the application of $360 \mathrm{~kg} \mathrm{~N} \mathrm{ha}^{-1}$ in 2014 (Table 5). As to the interaction of $N$ rate $\times$ application timing, the highest $\mathrm{RE}(59.7 \%)$ was obtained from the application of $120 \mathrm{~kg} \mathrm{~N}^{-1}$ three times in split ( $1 / 4$ at sowing, $1 / 2$ at tillering and $1 / 4$ at booting). However, the lowest value (25.64\%) was obtained from the application of $360 \mathrm{~kg} \mathrm{~N} \mathrm{ha}^{-1}$ two times equally at tillering and booting $\left(T_{3}\right)$ which is statistically similar to the recovery efficiency recorded when the highest level of nitrogen was applied only once at tillering (Table 7).

Table 7 Apparent nitrogen recovery efficiency (RE) and nitrogen harvest index (NHI) as influenced by the interaction effect of $\boldsymbol{N}$ fertilizer rate and time of $\boldsymbol{N}$ application

\begin{tabular}{|c|c|c|c|c|c|c|}
\hline \multirow[t]{3}{*}{$N$ timing } & \multicolumn{3}{|c|}{$N$ rate $\left(\mathrm{kg} \mathrm{ha}^{-1}\right)$} & \multicolumn{3}{|c|}{$N$ rate $\left(\mathrm{kg} \mathrm{ha}^{-1}\right)$} \\
\hline & 120 & 240 & 360 & 120 & 240 & 360 \\
\hline & \multicolumn{3}{|l|}{ RE \% } & \multicolumn{3}{|l|}{$\mathrm{NHI}(\%)$} \\
\hline$T_{1}$ & $56.1 a b$ & $42.71 d-f$ & $36.68 \mathrm{ef}$ & $80.99 a-c$ & $81.08 a-c$ & $79.21 \mathrm{a}-\mathrm{d}$ \\
\hline$T_{2}$ & $46.85 b-d$ & $35.48 \mathrm{fg}$ & $26.46 \mathrm{gh}$ & $83.75 a$ & $80.55 a-c$ & $80.81 a-c$ \\
\hline$T_{3}$ & $45.81 c-e$ & $35.53 \mathrm{fg}$ & $25.64 \mathrm{~h}$ & $81.45 a-c$ & $80.28 a-c$ & $78.22 b-d$ \\
\hline$T_{4}$ & $53.34 a-c$ & $48.19 b-d$ & $40.74 d-f$ & $76.66 \mathrm{~cd}$ & $76.68 \mathrm{~cd}$ & $76.39 \mathrm{~cd}$ \\
\hline$T_{5}$ & $59.24 a$ & $58.78 a$ & $47.92 b-d$ & $82.65 a b$ & $76.04 \mathrm{~cd}$ & $73.82 d$ \\
\hline CV (\%) & \multicolumn{3}{|l|}{11.94} & \multicolumn{3}{|l|}{3.82} \\
\hline
\end{tabular}

Means followed by the same letters for the same parameter are not significantly different at $P \leq 0.05$

CV Coefficient of variance

$T_{1}=N$ application $1 / 2$ at sowing and $1 / 2$ at tillering; $T_{2}=N$ application at tillering; $T_{3}=N$ application $1 / 2$ at tillering and $1 / 2$ booting; $T_{4}=N$ application $1 / 3$ at sowing, $1 / 3$ at tillering and $1 / 3$ at booting; and $T_{5}=N$ application $1 / 4$ at sowing, $1 / 2$ at tillering and $1 / 4$ at booting 


\section{Nitrogen harvest index}

Nitrogen harvest index is a measure of $N$ partitioning in the crop, which provides an indication of how efficiently the plant utilized the acquired $N$ for grain production [26]. Nitrogen harvest index (NHI) was significantly influenced by year, $N$ rate and timing of $N$ application. A generally significant effect of two-way interactions was also observed. However, the interaction effect of year $\times N$ rate $\times$ time of application was not significant (Table 2). With regard to the interaction effect of year $\times N$ rate, the highest value of NHI (84.13\%) during the first growing year (2014) and the lowest value (75.6\%) of NHI in the second growing year (2015) for wheat were recorded with the application of $120 \mathrm{~kg} \mathrm{~N} \mathrm{ha}^{-1}$ and $360 \mathrm{~kg} \mathrm{~N} \mathrm{ha}^{-1}$, respectively (Table 5). In general, application of nitrogen beyond $120 \mathrm{~kg} \mathrm{~N}^{-1}$ did not significantly affect $\mathrm{NHI}$ in the second growing season while the application of $360 \mathrm{~kg} \mathrm{~N}^{-1}$ significantly produced lower NHI as compared to the application of $120 \mathrm{~kg} \mathrm{~N}^{-1}$. With regard to the year $\times$ time of $N$ application, the highest NHI (83.35\%) was recorded when the whole nitrogen was applied only once at tillering $\left(T_{2}\right)$ which was statistically similar to the rest timing treatments in 2014, while the lowest NHI (71.72\%) was recorded with the split application of nitrogen three times $\left(T_{4}\right)$ in 2015 (Table 6). As to the interaction effect of $N$ rate $\times$ time of application, the highest value $(83.75 \%)$ was recorded due to the application of $120 \mathrm{~kg} \mathrm{~N} \mathrm{ha}^{-1}$ only once at tillering $\left(T_{2}\right)$, while the lowest nitrogen harvest index $(73.82 \%)$ was produced from the application of $360 \mathrm{~kg} \mathrm{~N} \mathrm{ha}^{-1}$ three times in split ( $1 / 4$ at sowing, $1 / 2$ at tillering and $1 / 4$ at booting) (Table 7 ).

\section{Discussion}

Variations in climatic conditions registered during the cropping periods (Fig. 1) induced large variations in grain yield and the efficiency of $N$ use by wheat. This agrees with Lopez-Bellido [28], who found a relationship between nitrogen fertilizer, wheat yield and seasonal trend, where there is a decline in yield during the wet years while little or no effect of $N$ fertilizer during the dry years.

\section{Grain yield}

In the current experiment, increase in the $N$ rate up to $240 \mathrm{~kg} \mathrm{~N} \mathrm{ha}^{-1}$ and splitting it three times $\left(T_{5}\right)$ had a positive effect on grain yield of wheat and were not significantly different with the application of $360 \mathrm{~kg} \mathrm{~N}$ ha $^{-1}$ with the same timing averaged over years. In general, the highest grain yield obtained in this experiment exceeds the yield obtained in response to the application of $120 \mathrm{~kg} \mathrm{~N} \mathrm{ha}^{-1}$ all at once at tillering by $57.8 \%$ (Table 3 ). Compared to the grain yield obtained from the control plot, the grain yields obtained from the aforementioned most productive treatments were superior by $392.1 \%$ and $372 \%$, respectively (Table 3 ). The optimum wheat grain yield was obtained in response to applying $240 \mathrm{~kg} \mathrm{~N} \mathrm{ha}^{-1}$ applied in three splits $1 / 4$ at sowing, $1 / 2$ at tillering stage of growth and $1 / 4$ at booting. This optimum yield exceeds the national average wheat yield of the country by about $152.5 \%$, which is about 2.4 ton $\mathrm{ha}^{-1}$ [3]. It also exceeds the world's average yield of $3.4 \mathrm{t} \mathrm{ha}^{-1}$ by about 78\% [29]. This indicates that evaluated $N$ rates positively affected grain yield. This dramatic yield increase with $N$ fertilizer application is the reason why farmers in the study area use higher rates of nitrogen $\left(256 \mathrm{~kg} \mathrm{ha}^{-1}\right)$ than the blanket recommendation $\left(87 \mathrm{~kg} \mathrm{ha}^{-1}\right)$. The increased grain yield due to the increased application of nitrogen might be attributed to the high concentration of $N$ in the leaves which increased and prolonged the photosynthesis ability of the plant which leads to an increase in grain yield. In agreement with the present result, Abedi [30] reported that different $N$ rates $\left(120,240\right.$ and $\left.360 \mathrm{~kg} \mathrm{ha}^{-1}\right)$ had a significant effect on grain yield increment in wheat $(46 \%$ at $N=120,72 \%$ at $N=240$, and $78 \%$ at $N=360$ ) compared to control.

The result of the current experiment also revealed that the application of $N$ three splits yielded more grain than application of nitrogen only once at tillering or just in two splits. The increase in grain yield due to the trice split application of nitrogen might be the better matching of $N$ availability with the crop needs during the growing period. Similarly, higher grain yield of wheat was reported when $N$ was applied in three splits (at planting, tillering and post-anthesis) compared with two splits (at planting and tillering) and one-time application (at planting) Brian [31]. Contrary to the current result, Chen and Neil [32] reported that split application of $N$ did not affect wheat grain yield significantly. Similarly, there was a report where applications of all $N$ rates at planting and twice split application timing showed the same significance effect on grain yield (each $5.4 \mathrm{t} \mathrm{ha}^{-1}$ ) with $8 \%$ higher yield over trice split $N$ timing [33]. The lowest value of grain yield in this experiment was recorded with the full application of $N$ only at tillering, where the applied $N$ was likely susceptible to leaching, denitrification and runoff loss as the amount of rainfall was higher during this period.

\section{Nitrogen uptake}

In this study, the highest GNUP was $118 \%$ higher than the lowest value which was obtained with the application of $120 \mathrm{~kg} \mathrm{~N} \mathrm{ha}^{-1}$ equally at tillering and booting (Table 3). The overall higher grain $N$ uptake due to the split application of the highest $N$ rate $\left(360 \mathrm{~kg} \mathrm{~N} \mathrm{ha}^{-1}\right)$ at sowing, tillering and booting $\left(T_{5}\right)$ can be explained by the 
more efficient $N$ mobilization to the grain at grain filling stage. This is in conformity with Jan [34] who reported higher efficiency of $N$ partitioning to the grain when $N$ was supplied in splits (at planting, tillering and stem elongation). Similarly, Fageria and Baligar [35] reported that split applications of nitrogen fertilizer cause high amount of nitrogen content to be taken by the grain rather than by straw of wheat. The present experiment also revealed nitrogen fertilizer rates significantly increased wheat $N$ uptake. Uptake values were similar in both growing years at lower $N$ rate, whereas significant differences were recorded between all fertilizer rates, rising as fertilizer rates increased. This might be because application of extra $N$ through increased levels increased the concentration of $N$ in the soil and led to greater absorption of nutrients, which ultimately resulted in vigorous growth of bread wheat in terms of higher dry matter accumulation and enhanced the total uptake of nitrogen. The result also revealed that the split application of the highest dose $\left(360 \mathrm{~kg} \mathrm{~N} \mathrm{ha}^{-1}\right)$ and applying it three times $\left(T_{5}\right)$ increased wheat $N$ uptake. The increased $N$ uptake of wheat due to the split application of nitrogen $\left(T_{5}\right)$ could be ascribed to the continuous supply of $N$ which may have increased the synchrony between plant $N$ demand and supply from the soil coupled with the reduction of $N$ losses via denitrification, leaching or runoff [4]. This proposition is consistent with the report of $N$ uptake by wheat crop which is significantly enhanced when application of the highest dose of $N$ fertilizer was done and synchronized with the time of high demand of the plant for uptake of the nutrient [36].

\section{Nitrogen use efficiency traits}

The present study demonstrated that a significant variation existed in the nitrogen use efficiency traits for year, rate and timing of $N$ applications. In 2015, the year with the highest grain yield had the highest $\mathrm{AE}$ and $\mathrm{RE}$ of wheat under the rate of $120 \mathrm{~kg} \mathrm{ha}^{-1}$ which were notably higher than the year 2014 under the same $N$ rate. The increase in $\mathrm{AE}$ and $\mathrm{RE}$ in the second growing season might be due to the absence of water logging which reduces the availability of nitrogen which is the problem of the first growing season. In general, $\mathrm{AE}$ diminished as the $N$ fertilizer rates increased in both growing seasons, with significant differences among all the levels of nitrogen. This result is in agreement with the finding of Roberts [37] who reported that increase in $N$ fertilizer rates resulted in a decline in agronomic efficiency. Higher AE could be obtained if the yield increment per unit $N$ applied is high because of reduced losses and increased uptake of $N$ [25]. Nitrogen agronomic efficiency value ranging from 10 to 30 is common, and values higher than 30 indicate efficiently managed systems [26]. Consistent with this suggestion, in this study $N$ application resulted in $\mathrm{AE}$ between 10.47 and $28.75 \mathrm{~kg} \mathrm{~kg}^{-1}$ in both the growing seasons, showing the importance of appropriate management system in wheat production.

The highest APE recorded in this study during the first wet growing season (2014) as a result of splitting nitrogen equally at tillering and booting implies that there was a higher loss of nitrogen in treatments where $N$ was applied during sowing time. However, in the second growing year (2015), time of application had less impact on APE since the loss of nitrogen was minimized as a result of reduction in waterlogging problem due to a lower amount of rainfall. In addition, the higher APE due to the split application of nitrogen in two splits (at tillering and booting) in both growing seasons might be attributed to adequacy of available nitrogen during grain development stage that might have increased the assimilation and redistribution of $N$ from the vegetative plant component to wheat grain. In contrast to the present finding, lower nitrogen utilization efficiency was reported in the early $N$ applications at planting and tillering compared with additional split application at anthesis [34].

The current experiment also revealed that the highest value of $59.8 \%$ for recovery efficiency (RE) was obtained with the triplicate application of $120 \mathrm{~kg} \mathrm{~N} \mathrm{ha}^{-1}\left(T_{5}\right)$ and it is $131 \%$ higher than the lowest value of $25.64 \%$ which was obtained with the application of the highest dose in two equal splits at tillering and booting. In line with the present result, Haile [36] reported $13.7 \%$ rise in recovery efficiency of nitrogen as a result of $N$ application three times $(1 / 4$ at sowing, $1 / 2$ at mid-tillering and $1 / 4$ at anthesis) at lower $N$ rate. The application of $N$ three times in split $\left(T_{5}\right)$ produced higher RE for all the $N$ rates tested in the current experiment. This implies if $N$ is applied in several small doses during the period of rapid crop growth, rather than as a single large dose at the beginning of rapid crop growth, then losses are minimized and crop recovery is maximized. Furthermore, the highest RE in the second growing season might be due to lower rainfall which improved the availability of nitrogen than the first growing season; thus, the crop has used the applied nitrogen more efficiently. The highest RE was recorded at a rate of $120 \mathrm{~kg} \mathrm{~N} \mathrm{ha}^{-1}$ in both growing seasons. In line with the current experiment, increase in apparent nitrogen recovery efficiency was reported at the rate of $150 \mathrm{~kg} \mathrm{~N} \mathrm{ha}^{-1}$ for wheat and barley [38]. In contrast, lower NUE (27.10\%) with the highest nitrogen rate of $120 \mathrm{~kg} \mathrm{~N} \mathrm{ha}^{-1}$ and the highest value (39.27\%) at the lowest $N$ rate of $30 \mathrm{~kg} \mathrm{~N} \mathrm{ha}^{-1}$ were reported on bread wheat [36]. However, nitrogen recovery may vary with the location, soil type, crop variety and the environmental conditions prevailing during the crop growth [39]. In conformity with this result, studies from Ethiopia reported highest apparent nitrogen recovery efficiency 
of $65.8 \%$ Selamyihun [40] and $39.27 \%$ [25] on wheat in Ethiopia. However, the common apparent recovery $N$-efficiency values ranging between 30 and $50 \%$, and 50 and $80 \%$ indicate well-managed system [27].

In the current experiment, application of nitrogen beyond $120 \mathrm{~kg} \mathrm{~N} \mathrm{ha}^{-1}$ did not significantly affect NHI in the second growing season while the application of $360 \mathrm{~kg} \mathrm{~N} \mathrm{ha}{ }^{-1}$ significantly produced lower NHI as compared to the application of $120 \mathrm{~kg} \mathrm{~N} \mathrm{ha}^{-1}$. The first growing season produced the highest NHI than the second growing season under all the levels of $N$. This showed a strong influence of rainfall, in the variable response of NHI to time of application. The higher $\mathrm{NHI}$ during the first growing season might be due to the production of a lower aboveground biomass yield due to water logging, which resulted from higher rainfall. The lower NHI in the second growing as compared to the first growing season might be attributed to the increase in aboveground biomass yield. In general, the highest NHI value was recorded when nitrogen was applied only at tillering during both growing seasons. This might be due to the lowest aboveground biomass and grain yield produced by this treatment. Similarly, a higher nitrogen harvest index for wheat was obtained with treatments which produced the least aboveground biomass and grain yield [41].

\section{Conclusion}

The results of this study have demonstrated that application of a large quantity of nitrogen (a minimum of $240 \mathrm{~kg} \mathrm{~N} \mathrm{ha}^{-1}$ ) in three split doses $\left(T_{5}\right)$ was required to obtain optimum wheat yield, which is about 2.5fold higher than the national average yield of the crop in Ethiopia. The soil requires application of as much as $240 \mathrm{~kg} \mathrm{~N} \mathrm{ha}^{-1}$ to produce about 6 tons of wheat per hectare which implies that the soil is productive unless the nitrogen uptake efficiency of the crop possibly is reduced as a result of its characteristic waterlogging condition. The importance of splitting nitrogen in three split doses $(1 / 4$ th at sowing, $1 / 2$ at tillering and the other $1 / 4$ th at booting) was also evidenced in the optimum yields and improving nitrogen recovery. Nitrogen fertilizer led to a general decrease of nitrogen use efficiency traits in both growing years. Higher $N$ level increased $N$ content in the grain and nitrogen uptake by wheat crop. In view of the current result, the significant interaction with year indicates that the efficiency of broad bed and furrows to drain excess soil moisture is lower in years which receive a higher amount of rainfall. Therefore, it should be supported by developing wheat varieties tolerant or resistant to such shocks.

\section{Abbreviations}

AE: agronomic efficiency; APE: agro-physiological efficiency; CV: coefficient of variation; GNUP: grain nitrogen uptake; GY: grain yield; MoARD: Ministry of Agriculture and Rural Development; N: nitrogen; NHI: nitrogen harvest index; NUE: nitrogen use efficiency; RE: recovery efficiency; TNUP: total nitrogen uptake.

\section{Authors' contributions \\ FB conceived the study and design, collected the data, performed the analysis on all samples, interpreted the data, wrote the manuscript and acted as cor- responding author. ND, AM and TT assisted in analysis and interpretation of data and drafting of the manuscript. All authors read and approved the final manuscript.}

\section{Author details \\ ${ }^{1}$ School of Plant Sciences, College of Agriculture and Environmental Sciences, Haramaya University, P.O. Box 138, Dire Dawa, Ethiopia. ${ }^{2}$ Department of Plant Sciences, College of Agriculture and Natural Resource Sciences, Debre Berhan University, P.O. Box 445, Debre Berhan, Ethiopia. ${ }^{3}$ Chickpea and Malt Barley- Faba Bean Projects ICARDA, Addis Ababa, Ethiopia.}

\section{Acknowledgements}

The authors would like to thank Debre Berhan Agricultural Research Center for providing the land and allowing us to use their facilities and Debre Berhan University for allowing the corresponding author a leave of absence to conduct PHD dissertation research from which this article was emanated.

\section{Competing interests}

The authors declare that they have no competing interests.

\section{Availability of data and materials}

The authors want to declare that they can submit the data at whatever time based on your request. The data used for the current study are available from the corresponding author on reasonable request.

\section{Consent for publication}

Not applicable.

Ethics approval and consent to participate

Not applicable.

\section{Funding}

All authors dedicated their additional working hours to develop this paper with no specific grant from any funding agency.

\section{Publisher's Note}

Springer Nature remains neutral with regard to jurisdictional claims in published maps and institutional affiliations.

Received: 25 September 2018 Accepted: 7 December 2018

Published online: 17 December 2018

\section{References}

1. Shewry PR. Wheat. J Exp Bot. 2009;60(6):1537-53.

2. FAOSTAT. online [Internet]. 2014 [cited 2015 Mar 6]. Available from: http:// faostat.fao.org/site/291/default.aspx.

3. CSA (Central Statistic Agency). AGricultural Sample Survey Report on Area and Production of Major Crops for the period 2015/2016 cropping season volume I. Statistical bulletin 584, Addis Ababa, Ethiopia. vol. 584, Statistical Bulletin. 2016

4. Tilman D, Cassman K, Matson P, Naylor R, Polasky S. Agricultural sustainability and intensive production practices. Nature. 2002;418:671-7.

5. Good A, Shrawat K, Muench G. Can less yield more? Is reducing nutrient input into the environment compatible with maintaining crop production? Trends Plant Sci. 2004;9(12):597-605.

6. Teklu E, Hailemariam T. Agronomic and Economic Efficiency of Manure and Urea Fertilizers Use on Vertisols in Ethiopian Highlands. Agric Sci China. 2009;8(3):352-60. https://doi.org/10.1016/S1671-2927(08)60219-9. 
7. Carranca C. Nitrogen use efficiency by annual and perennial crops. In: Lichtfouse E, editor. Farming for food and water security. Berlin: Springer; 2012. p. 57-82.

8. Raun WR, Johnson GV. Improving nitrogen use efficiency for cereal production. Agron J. 1999;91:357-63.

9. Moll RH, Kamprath EJ, Jackson WA. Analysis and interpretation of factors which contribute to efficiency of nitrogen utilization. Agron J. 1982;74(3):562.

10. Huggins D, Pan W. Key indicators for assessing nitrogen use efficiency in cereal-based agroecosystems. J Crop Prod. 2003;8(1-2):157-85.

11. Legg JO, Meisinger JJ. Soil nitrogen budgets. In: Stevenson FJ, editor Nitrogen in agricultural soils. Madison: American Society of Agronomy; 1982. p. 503-66

12. Gehl RJ, Schmidt JP, Maddux LD, Gordon WB. Corn yield response to nitrogen rate and timing in sandy irrigated soils. Agron J. 2005;97(4):1230-8.

13. Anthony $G$, Woodard B, Hoard J. Foliar $N$ application timing influence on grain yield and protein concentration of hard red winter and spring wheat. Argon J. 2003;95:335-8.

14. López-Bellido JRR, López-Bellido L. Efficiency of nitrogen in wheat under Mediterranean conditions: effect of tillage, crop rotation and $N$ fertilization. F Crop Res. 2001;71(1):31-46

15. Brian NO, Mohamed M, Joel KR. Seeding rate and nitrogen management effects on spring wheat yield and yield components. Am J Agron. 2007;99:1615-21.

16. Molla A. On-farm participatory evaluation of bread wheat productivity under different NP levels, precursor crops, and Vertisols types in the highlands of central Ethiopia. In: Achievements of integrated crop, soil and water management research activities on wheat. EAAP/EIAR. Addis Abeba, Ethiopia; 2015

17. Page AL, Miller RH, Keeney. DR. Methods of Soil Analysis. Part 2. Chemical and Microbiological Properties. 2nd edn. Soil Science Society of America; Madison, Wisconsin, U.S.A. 1982

18. MoARD (Ministry of Agriculture and Rural Development. Crop variety register. Animal and plant health regulatory directorate Issue No.12. June, 2009. Addis Ababa, Ethiopia. 2009

19. Zadoks JC, Chang TT, Konzak CF. A decimal code for the growth stages of cereals. Weed Res. 1974;14:415-21.

20. Molla A. Farmers' knowledge helps develop site specific fertilizer rate recommendations, central highlands of Ethiopia. World Appl Sci J. 2013;22(4):555-63.

21. American Association Cereal Chemists (AACC). Approved Methods of the American Association Cereal Chemists. American Association of Cereal Chemists, Inc., St. Paul, Minnesota; 2000.

22. Fageria NK. Nitrogen management in crop production. Boca Raton: CRC Press; 2014

23. SAS Institute Inc. SAS ${ }^{\circledR} 9.3$ Companion for Windows. Cary, NC: SAS Institute Inc. Cary, NC, USA; 2011.

24. Gomez KA, Gomez AA. Statistical procedures for agricultural research. New York: Wiley; 1984

25. Craswell ET, Godwin DC. The efficiency of nitrogen fertilizers applied to cereals in different climates. Adv Plant Nutr. 1984;1:1-55.

26. Dobermann AR. Nitrogen Use Efficiency - State of the Art. Univ Nebraska. 2005;17.

27. Fageria NK, Baligar VC, Jones CA. Growth and mineral nutrition of field crops. 3rd ed. New York: Taylor, Francis Group; 2011. p. 530.
28. López-Bellido L, López-Bellido RJ, Redondo R. Nitrogen efficiency in wheat under rainfed Mediterranean conditions as affected by split nitrogen application. F Crop Res. 2005;94:86-97.

29. MAFAP (Monitoring African Food and Agriculture Policies). Improving incentives to expand wheat production in Ethiopia. Policies Brief, \#9. 2013.

30. Abedi T, Alemzadeh A, Kazemeini SA. Wheat yield and grain protein response to nitrogen amount and timing. Aust J Crop Sci. 2011:5(3):330-6.

31. Brian NO, Mohamed M, Joel KR, Otteson BN, Mergoum M, Ransom JK, et al. Seeding rate and nitrogen management effects on spring wheat yield and yield components. Am J Agron. 2007;99(6):1615-21.

32. Chen $C$, Neill K. Response of spring wheat yield and protein to row spacing, plant density, and nitrogen application in Central Montana. In: Fertilizer Fact: No.37. Montana State University, Agricultural Experiment Station and Extension Service, USA. 2006:

33. Chibsa T, Gebrekidan H, Kibret K, Tolessa D. Effect of rate and time of nitrogen fertilizer application on durum wheat (Triticum turgidum Var L. Durum) grown on Vertisols of Bale highlands, southeastern Ethiopia. Am J Res Commun. 2016:5(1):39-56.

34. Jan MT, Khan JM, Khan A, Arif M, Shafi M, Nullah N. Wheat nitrogen indices response to nitrogen source and application time. Pak J Bot. 2010;42(6):4267-79.

35. Fageria NK, Baligar VC. Enhancing nitrogen use efficiency in crop plants Adv Agron. 2005;88:97-185.

36. Haile D, Nigussie D, Ayana A. Nitrogen use efficiency of bread wheat: effects of nitrogen rate and time of application. J Soil Sci Plant Nutr. 2012;12(123):389-409.

37. Roberts TL. Improving nutrient use efficiency. Turk J Agric 2008;32:177-82.

38. Delogu G, Cattivelli L, Pecchioni N, De Falcis D, Maggiore T, Stanca AM Uptake and agronomic efficiency of nitrogen in winter barley and winter wheat. Eur J Agron. 1998;9(1):11-20.

39. Sinebo W, Gretzmacher R, Edelbauer A. Genotypic variation for nitrogen use efficiency in Ethiopian barley. F Crop Res. 2004;85:43-60.

40. Selamyihun K, Tanner DG, Tekalign M. Residual effects of nitrogen fertilizer on the yield and $N$ composition of succeeding cereal crops and on soil chemical properties of an Ethiopian highland Vertisol. Can J Soil Sci. 2000;80:63-9

41. López-Bellido L, López-Bellido RJRJ, Redondo R. Nitrogen efficiency in wheat under rainfed Mediterranean conditions as affected by split nitrogen application. F Crop Res. 2005:94(1):86-97.

42. Tadesse T. Soil, plant, water, fertilizer, animal manure and compost analysis manual: Plant Science Division Working Document No. 13. Addis Ababa, Ethiopia: International Livestock Center for Africa. 1991.

43. Olsen SR, Cole CV, Watandbe FS, Dean LA. Estimation of available Phosphorus in soil by extraction with Sodium Bicarbonate. J Chem Inf Model. 1954;53(9):1689-99.

44. Metson AJ. Methods of chemical analysis for soil survey samples. Soil Bureau Bulletin No. 12, New Zealand Department of Scientific and Industrial Research. Government Printer: Wellington, New Zealand; 1961. p. 168-75. 